\title{
A mesterséges intelligencia egyes felhasználási lehetőségei a rendvédelmi területeken
}

\section{DOBÓ Judit ${ }^{1}$ - GYARAKI Réka² ${ }^{2}$}

\begin{abstract}
Mindannyian hallottunk már a mesterséges intelligenciáról, de csak kevesekben realizálódik, mennyire átszövi és meghatározza korunk technológiai fejlödését. Azonban a népszerú gazdasági és tudományos érdekek mellett legalább olyan fontos, hogy a közbiztonság terén is hasznos szolgálatot tegyen. Jövőbeli hasznosítása ugyanakkor komoly kihívások elé állítja mind a rendvédelmi területet, mind pedig a jogalkotást. Az, hogy ezeket a kihívásokat miként lehet majd leküzdeni, az elkövetkező idők legfontosabb kérdése lesz.
\end{abstract}

Kulcsszavak: mesterséges intelligencia, bűnüldözés, elemzés, arcfelismerés

\section{Bevezetés}

A mesterséges intelligencia (MI) a gépek emberhez hasonló képességeit jelenti, mint például az érvelés, a tanulás, a tervezés és a kreativitás lehetőségét.

$\mathrm{Az}$ MI lehetővé teszi a technika számára, hogy érzékelje környezetét, foglalkozzon azzal, amit észlel, problémákat oldjon meg, és konkrét cél elérése érdekében tervezze meg lépéseit. A számítógép nemcsak adatokat fogad (már előkészített vagy összegyưjtött adatokat érzékelőin, például kameráján keresztül), hanem fel is dolgozza azokat, és reagál rájuk.

Ezek a rendszerek képesek viselkedésük bizonyos fokú módosítására is, a korábbi lépéseik hatásainak elemzésével és önálló munkával.

A mesterséges intelligencia az emberi intelligencia szimulációjára utal olyan gépekben, amelyek úgy vannak beprogramozva, hogy úgy gondolkodjanak, mint az emberek, és utánozzák cselekedeteiket. A kifejezés alkalmazható minden olyan gépre is,

Dobó Judit rendőr tisztjelölt, Nemzeti Közszolgálati Egyetem Rendészettudományi Kar, végzős tisztjelölt, bűnüldözési szakirányos hallgató; Bűnügyi, Gazdaságvédelmi és Kiberbűnözés Elleni Tanszék, demonstrátor. Judit Dobó graduate police officer candidate, University of Public Service Faculty of Law Enforcement Department of Criminal Investigation, Economy Protection and Cybercrime Prevention, Demonstrator. E-mail: dobo.judith@ gmail.com

2 Dr. Gyaraki Réka r. őrnagy, Nemzeti Közszolgálati Egyetem Rendészettudományi Kar Bűnüldözési, Gazdaságvédelmi és Kiberbűnözés Elleni Tanszék, egyetemi tanársegéd; Rendészettudományi Doktori Iskola, doktori hallgató.

Réka Gyaraki Police Major University of Public Service Faculty of Law Enforcement Department of Criminal Investigation, Economy Protection and Cybercrime Prevention, Assistant Lecturer, Doctoral School of Police Sciences and Law Enforcement, PhD student. E-mail: Gyaraki.Reka@uni-nke.hu 
amely olyan tulajdonságokkal rendelkezik, mint az emberi elme, például a tanulás és a problémamegoldás terén.

A tanulmányban bemutatjuk a mesterséges intelligencia már hazánkban is használt alkalmazási lehetőségét a bűnüldözésben és a bűnmegelőzésben. A bűncselekmények megelőzésére, szabálysértések visszaszorítására, az elkövetők személyének rögzítésére már számos városban, településen helyeztek el köztéri kamerákat. A nagyobb területekre kihelyezett térfigyelő kamerák mellett üzletekben, zárt helyiségben is láthatunk bünözők visszaszorítására telepített áruvédelmi rendszereket.

A tanulmányban arra keresünk választ, hogy milyen törvényi vagy egyéb szabályozási előírásokkal lehet elérni, hogy az egyéntől, környezetből származó adatok megfelelők (vagy legalábbis minél kisebb hamis érteket tartalmazók) legyenek.

Kutatásunk egyrészről leíró jellegú, mivel a hazai mesterségesintelligenciakutatásban nagyon kevés irányul a rendvédelmi alkalmazásokra, illetve jelenleg a hazai rendészettudomány területén még nincs arra vonatkozó kutatás, hogy a mesterséges intelligencia egyes területeit hogyan lehet alkalmazni a rendvédelemben. ${ }^{3}$ Ugyanakkor Dobó Judit a TDK-témájának választott területhez ${ }^{4}$ a rendőrség állományával egy kérdőíves kutatást végzett, amelynek célja a mesterséges intelligencia adta rendészeti lehetőségek, az egyes újítások és azok alkalmazásának mérése, valamint az állomány tájékozottságának vizsgálata volt.

A Szent-György Szakkollégium Kiber Kutatómühelyben a hallgatókkal közös célkitűzésünk, hogy a mesterséges intelligencia különböző felhasználási területeit feltérképezzük, alkalmazásának lehetőségeit megismerjük és publikáljuk.

A kutatás azért különösen fontos, mivel az emberi elme és tapasztalás már nem elégséges a technológiai fejlődés, valamint az általa generált bűncselekmények és kihívások kezeléséhez.

A mesterséges intelligencia felhasználásának számos területe van, így az orvostudományon kívül alkalmazzák a matematika és statisztika területén, a kommunikációés nyelvtudományokban, a műszaki tudományokban, a számítástechnikában és pszichológiában, több más tudományterület mellett.

A tanulmány szempontjából az egyik kiemelt terület a biztonságtudományok területe, amelyen belül az MI rendvédelmi alkalmazhatóságáról írunk részletesebben. A biztonságtudományban, ahogy Kollár említi, a forenzikus területet, valamint a képfelismerés és -elemzés területét részletezzük.

A Nemzeti Közszolgálati Egyetem Rendészettudományi Karon a büntetés-végrehajtási alkalmazásával összefüggésben kezdődtek már kutatások.

4 A mesterséges intelligencia alkalmazása a rendvédelemben című dolgozat a 2021. április 23-án megrendezésre került XXXV. Országos Tudományos Diákköri Konferencián Had- és Rendészettudományi Szekcióban, Általános rendészeti tagozatban első helyezést ért el, valamint a Rendészeti Doktoranduszok Országos Egyesületének különdíját is megkapta. 


\section{A mesterséges intelligencia története}

A Warren McCulloch és Walter Pitts által elérteket az MI kialakulása kezdetének tartják. ${ }^{5}$ Három forrásból merítettek: az alapszintű fiziológiai és az agyi neuronok múködésére vonatkozó ismeretekből, az ítéletkalkulus Russell és Whitehead-féle formális elemzésből és Turing számításelméletéből.

A Turing-teszt arra az álláspontra helyezkedik, hogy abban az esetben, ha képesek lennénk egy olyan megfelelően programozott számítógépet létrehozni, amely tetszőleges témáról úgy tudna beszélgetni egy emberi féllel, hogy az nem tudná megállapítani, hogy egy számítógéppel vagy egy másik élő emberrel folytat eszmecserét, akkor feltételeznünk kellene, hogy a gép intelligens. A Turing-teszt néven elhíresült kísérletben egy kérdezőbiztos feladata lenne a fenti következtetés megállapítása, úgy, hogy egy billentyưzet és monitor segítségével tartaná a kapcsolatot a másik szobában levő tesztalannyal, akinek kérdéseket kellene feltennie, majd ezek után kell kitalálnia, hogy számítógéppel vagy emberrel beszélt. ${ }^{6}$

A tényleges mesterséges intelligencia megszületésének dátuma 1956, amikor Allen Newell és Herbert Simon egy munkatalálkozó során bemutatták azt a találmányukat, amelyről Simon már úgy vélekedett, hogy egy nem numerikus gondolkodó program, amely majd a későbbiekben bebizonyította Whitehead matematikai tételeinek többségét. A mesterséges intelligencia tényleges iparággá válására azonban 1980-ig kellett várni, amikortól is felgyorsult az MI fejlődése, fejlesztésének és használatának kiterjesztése. Olyannyira, hogy 1987-től már tudománnyá is vált.?

\section{Kérdőives kutatás a rendészeti állomány tagjaival ${ }^{8}$}

A Magyar Rendőrség jelenleg még csekély mértékben használja a mesterséges intelligencia által kínált lehetőségeket. Egy, a rendvédelemben dolgozó állomány körében elvégzett kutatás alapján az látható, hogy a rendészeti dolgozók mesterséges intelligenciával összefüggő ismeretei a témával kapcsolatban akár felszínesnek is mondhatók, amit az elvégzett kérdôíves kutatás is bizonyít. A 315 válaszadó hivatásos állományú tag közel háromnegyede 26 és 50 év közötti életkorú személy, 18\% annál idősebb, és csupán $8 \%$ annál fiatalabb személy. Érdekesség, hogy a megkérdezettek több mint kétharmada rendelkezik felsőoktatási képesítéssel.

A következőkben csak nagyon röviden ismertetjük a Dobó Judit által engedéllyel elvégzett felmérést.

Warren McCulloch - Walter Pitts: A Logical Calculus of the Ideas Immanent in Nervous Activity. Bulletin of Mathematical Biophysics, 5. (1943). 115-133.

Mesterséges intelligencia kisokos: https://atozofai.withgoogle.com/intl/hu/turing-test/

A mesterséges intelligencia története: http://project.mit.bme.hu/mi_almanach/books/aima/ch01s03

Dobó Judit: A mesterséges intelligencia alkalmazása a rendvédelemben. Tudományos Diákköri Konferencia dolgozat. Budapest, 2020. november. 4. 
A kutatás első kérdése arra fókuszált, hogy a rendészeti dolgozók tisztában vannak-e azzal, mit jelent maga a mesterséges intelligencia. Többségben valamilyen, az MI-hez ténylegesen köthető tartalmi elemet írtak le, ám az hiányos vagy kevés volt. Sok olyan válaszadó - $10 \%$ - volt, akik egyáltalán nem tudták azt leírni, vagy nem hozzá köthető választ adtak.

A válaszadók az alábbi szavakat írták:

- gépi tanulás;

- önálló tanulásra képes program;

- önálló döntéshozatalra, minták felismerésére képes algoritmus;

- mesterségesen létrehozott program, amely önállóan reagál a külvilág változásaira;

- emberi tudással felvértezett gépek;

- számítógépes algoritmus.

Ugyanakkor elenyésző volt azok száma, akik ténylegesen meg tudták jelölni az MI „kötelezô" tartalmi tényezőit. Persze mostanra tudjuk, hogy lehetetlen egységes fogalmat kialakítani magára a mesterséges intelligenciára, ettől függetlenül a kitöltők többsége az MI-hez köthető valamely alcsoportra, például a robotikára asszociált, amikor az MI-re kellett választ adnia. ${ }^{9}$

A második kérdés arra irányult, hogy a kitöltők korábban kaptak-e valamilyen tájékoztatást az MI-ről, annak rendészeti lehetőségeiről. Közel 90\%-uk adott nemleges választ. Szintén kevesen tudtak válaszolni arra is, hogy milyen MI-vel kapcsolatos lehetőségeket ismernek, amelyek a rendészeti munkát segíthetik. A megkérdezettek közel fele olyan programot írt, amelyet nem lehet mesterséges intelligenciához kötni (tipikus válasz volt az okostelefon vagy a Robotzsaru), de sokan egyáltalán nem tudtak válaszolni. Amikor viszont konkrét lehetőségekből kellett kiválasztani azokat a mesterséges intelligenciához köthető rendszereket, amelyeket a válaszadó korábbi munkája során használhatott, több mint 150 válaszadó jelölte, hogy használta már az arcképazonosító rendszert. Látható tehát, hogy a megkérdezettek ugyan nem tudják meghatározni magát az MI-t, és nem is igazán tudnak hozzá köthető rendszereket mondani, ám ez nem zárja ki azt, hogy egyébként ne tudnák alkalmazni az adott szoftvert - mint az arckép-azonosító rendszert - legfeljebb nem tudják, hogy az MI-hez köthető.

Abban a kérdésben, hogy a mesterséges intelligencia támogatná-e a munkájukat, $70 \%$ válaszolt egyértelmú igennel, és csupán három személy jelölte az MI-t hátráltató tényezőként. Mindezek alapján elmondható, hogy az állomány részére történő rendészeti vonatkozású lehetőségek ismertetése, oktatása nem lenne eredménytelen. A rendészeti dolgozók érdeklődését támasztják alá azok a válaszok is, ahol a kérdés arra irányult, milyen minőségben támogatnának egy mesterséges intelligenciával, annak

Dobó Judit: A mesterséges intelligencia alkalmazása a rendvédelemben. NKE RTK Tudományos Diákköri Konferencia, 2020. november 4 . 
rendészeti lehetőségeivel kapcsolatos képzést. Érdekesség, hogy válaszadók közel 70\%-a szívesen részt venne ilyen programon, képzésen, fontosnak találja azokat.

Összességében a mesterséges intelligencia adta rendészeti lehetőségek és újítások mérésére, valamint az állomány tájékozottságának vizsgálatára irányuló kérdőív válaszai alapján azt mondhatjuk, hogy a hivatásos állomány tagjainak tudása a témában hiányos, de ezen túl a kitöltők nagy része láthatóan támogatna valamilyen, a mesterséges intelligenciával kapcsolatos képzést, tájékoztatást, érdeklődik a mesterséges intelligencia adta lehetőségek iránt, amit mindenképpen hasznos és érdemes lenne kihasználni, ha annak rendészeti célú felhasználási lehetőségeiről beszélünk.

$\mathrm{Az}$ alábbi két diagram annak bemutatása, hogy a rendvédelemben milyen fogadtatása lenne a mesterséges intelligenciának:

A mesterséges intelligencia adta lehetőségek milyen hatással bírnak önre munkája során?

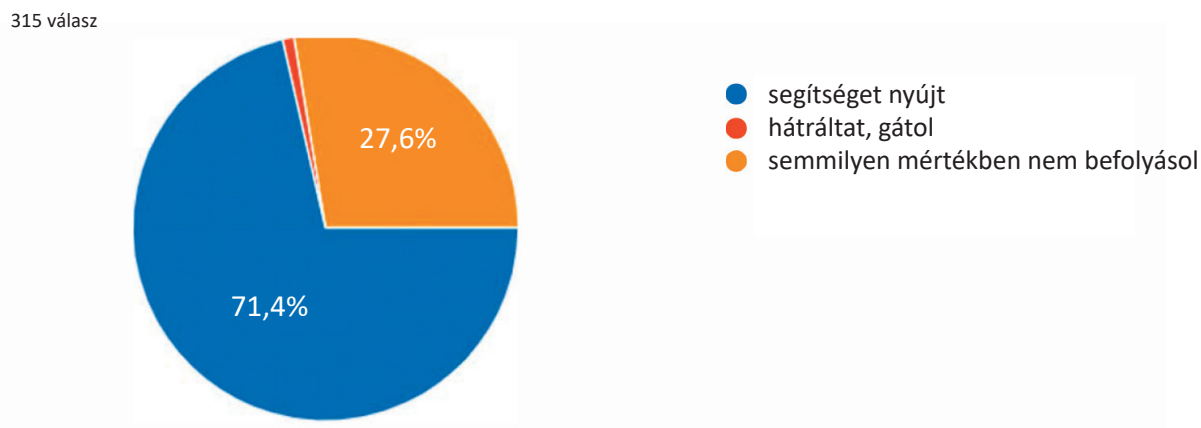

1. ábra: A mesterséges intelligenciához való hozzáállás vizsgálata

Forrás: Dobó Judit szerkesztése

Tàmogatna egy, a mesterséges intelligencia alapú programok kezelésének bemutatàsát szorgalmazó oktatást, képzést a hivatásos àllomány részére?

315 válasz

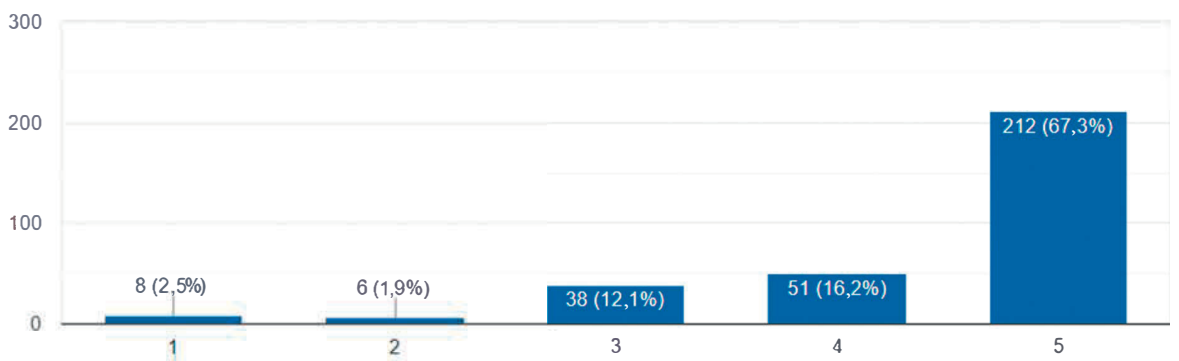

2. ábra: A mesterséges intelligencia alapú rendszerek támogatottságának vizsgálata 


\section{Az MI lehetőségei a rendvédelemben}

Az alábbi felsorolásban azok a lehetőségek láthatók, amelyeket megfelelő adatbázishoz vagy rendszerhez történő hozzáférés esetén - értve ezalatt a megfelelő menynyiségú és minőségű adatokat - alkalmasak arra, hogy az MI felhasználását rendészeti területen akár a bűnüldözés, a felderítés vagy a bűnmegelőzés szempontjából érdemes vizsgálni.

A biztonságtudományhoz tartozó forenzikus területek:

- elkövetői csoportok megrajzolása;

- elkövetői profil megrajzolása;

- felderítés;

- kapcsolati hálók feltérképezése;

- kép-, hang- és szövegfelismerés;

- mintázatok felismerése;

- nyomkövetés, haladási útvonal predikciója.

A képfelismerés és -elemzés:

- arcfelismerés;

- arcfelismerés, beazonosítás, megkülönböztetés másoktól;

- bonyolultabb alakfelismerés;

- mozgásfelismerés;

- részletkutatás. ${ }^{10}$

De idesorolható még a kockázatelemzés, a szövegfelismerés és -elemzés, a kiberbiztonság vagy az általános biztonságtechnikai területek is. ${ }^{11}$

\subsection{Az arckép felismerése}

Az arcfelismerés során általában két módszert alkalmaznak: egyrészt a mintaalapú (vagy fotometrikus) módszert, amelyben az arc vagy az arcrészek (például szem, száj) globális jellemzőit összehasonlítják a tárolt mintákkal, másrészt a geometriai alapú módszert, ahol az arc bizonyos részleteit (szem, orr, áll stb.) egymáshoz viszonyított helyzetük és méreteik alapján elemzik. ${ }^{12}$

10 Kollár Csaba: A mesterséges intelligencia kapcsolata a humán biztonsággal. Nemzetbiztonsági Szemle, 6. (2018), 1. 5-23.

11 Kollár Csaba: A mesterséges intelligencia és a kapcsolódó technológiák bemutatása a biztonságtudomány fókuszában. In Rajnai Zoltán (szerk.): Kiberbiztonság/Cybersecurity 2. Budapest, Biztonságtudományi Doktori Iskola, 2019. 47-61.

12 Németh Attila - Tóth Gergely: Arcfelismerő rendszerek alkalmazása. Belügyi Szemle, 67. (2019), 1. 129. 


\subsubsection{Az arckép-azonositó rendszer}

A (arc)kép-azonosítási rendszer igazi segítséget jelenthet a rendvédelmi és a nemzetbiztonsági elemzőknek - akár a magánbiztonság szereplőit is szükséges lenne említeni, de az MI ezen szegmensét most nem vizsgáljuk -; például gyakran az arcképekre támaszkodva tudják meghatározni a személyek identitását és tartózkodási helyét. Az esetlegesen releváns képek és videók hatalmas mennyiségének pontos vizsgálata időigényes, nehéz feladat, tele hibalehetőségekkel. Ezek a hibák, tévedések adódhatnak az emberre jellemző gyengeségekből, így például a fáradtság, figyelmetlenség stb., amelyek a mesterséges intelligencia esetében korlátozhatók annak fejlesztésével, az adatok pontos bevitelével, a fáradtság és a figyelmetlenség pedig egy gép esetén egyenesen kizárt.

Az utóbbi években a különböző arc- és képfelismerő programok komoly fejlödésen estek át, ami széles körủ elterjedést és alkalmazhatóságot eredményezett. Kísérleti jelleggel már számos helyen alkalmazzák azokat az arcfelismerő programokat, amelyek a felhasználók kényelmét szolgálják: használjuk őket a mobiltelefonunk feloldásához, az egyes fényképeken való megjelenés felismeréséhez, de mára már egyáltalán nem ritkák azok az arcfelismerést végző applikációk sem, amelyek a vevők banki adataival összekötve mesterségesintelligencia-rendszereknek köszönhetően lehetôvé teszik, hogy sorbaállás és fizetés nélkül távozzanak a pénztártól a vevők, hiszen az ellenértéket automatikusan levonják. ${ }^{13} \mathrm{Az}$ ilyen kényelmi alapon müködő arcfelismerést a rendészeti munkában is kiválóan, sőt egyre hatékonyabban alkalmazzák. Ettől függetlenül az úgynevezett állóképes arckép-azonosító rendszer mint azonosítást, ellenőrzést segítő rendszer igen kevés figyelmet kapott ahhoz képest, milyen gyorsan fejlődő területről beszélünk. Automatizált rendszerek létrehozására már az 1940-es években is volt törekvés, ám sikeres előrelépést csak 2013-ban tudtunk elérni, amikor az Országos Rendőr-főkapitányság arcképprofil-nyilvántartást hozott létre. Az állóképes arcfelismerő rendszer múködése 2016. március 15-én kezdődött meg, amit az arcképelemzési nyilvántartásról és az arcképelemző rendszerről szóló 2015. évi CLXXXVIII. törvény elfogadása előzött meg.

\subsubsection{Az állóképes arckép-azonositó rendszer}

$\mathrm{Az}$ arcfelismerő rendszerek az elmúlt években jelentős fejlődésen mentek keresztül a világon, a mesterséges intelligencia és a Deep Learning (mély tanulási) algoritmusok miatt.

13 Szalavetz Andrea: Mesterséges intelligencia és technológiavezérelt termelékenységemelkedés. Külgazdaság, 63. (2019), 7-8. 58. 
Arcfelismerő rendszerek esetén két csoportról beszélhetünk. Egyrészt a képalapú, másrészt a videóalapú arcfelismerésről. Jelen tanulmány során a viselkedésalapú rendszerek mellett az állóképes arcfelismerésről lesz szó.

$\mathrm{Az}$ állóképes arckép-azonosító rendszert a bűnügyi, bűnmegelőzési, rendészeti célú felhasználás, a nemzetbiztonsági érdekből történő felhasználás, esetleg határrendészeti, menekültügyi és idegenrendészeti feladatok támogatásának tekintetében alkalmazzák. A program kialakításával az volt a cél, hogy olyan arcképeket nyilvántartó rendszert hozzanak létre, amely támogatja a jogosult szervek irányába történő személyazonosításra irányuló adatigénylést. ${ }^{14} \mathrm{Az}$ állóképes arckép-azonosító rendszer működése a Belügyminisztérium feladatai közé tartozik, az arcfelismerési elemzés pedig előbb a Közigazgatási és Elektronikus Közszolgáltatások Központi Hivatalának (KEKKH) feladata volt, majd 2017. január 1-jétől bekerült a Nemzeti Szakértői és Kutató Központ (NSZKK) funkciói közé. ${ }^{15}$

A rendszer múködésének alapját az adja, hogy egy keresőprogram összehasonlítja az elemzésre beküldött képet az adatbázisban tárolt képekkel a geometriai arcfelismerés módszerével. A vizsgálat során a feltöltött képből arcképprofilt képeznek, majd úgynevezett manipulációs eljárás után a feltöltött képből képzett arcképprofilt összehasonlítják a tárolt képekből készített arcképprofillal. Eredményként valószínúségi sorrendet és egy pontszámot kapunk: a rendszer pontozza a találatokat aszerint, hogy milyen szintű a hasonlóság a képek között. ${ }^{16} \mathrm{~A}$ beérkezett kérelmeket két elemző személy dolgozza fel egymástól függetlenül, amelynek során az algoritmus által hasonlónak vélt találatokat egyesével összehasonlítják az elemzésre beküldött képpel, majd a folyamat végét egy vezetői ellenőrzés zárja. Látható, hogy a rendszer azt az óriási adathalmazt fésüli át - igen rövid idő alatt -, amelyet humán erőforrással valószínúleg képtelenség lenne.

\subsubsection{Adatigénylés}

Az eljárás normál határideje nyolc munkanap, ugyanakkor egyes esetben van lehetőség soron kívüli adatigénylésre, amelynek 24 órán belül kell történnie. Soron kívüliségre ad okot kiskorú személy veszélyeztetettsége, a közbiztonságot vagy nemzetbiztonságot közvetlenül és súlyosan fenyegető helyzet, esetleg a kiemelt bűnüldözési érdek. Az adatigénylés történhet azonnali határidővel is, ez két órán belüli adatszolgáltatást jelent. Ez utóbbi esetébe tartoznak a különleges jogrendben alkalmazandó intézkedések, de a tömeges bevándorlás okozta válsághelyzet kezelése is. ${ }^{17} \mathrm{Az}$ adatigénylés eredményességének növelésére az elemzéshez több különböző

\footnotetext{
Az arcképelemző rendszer működtetésének részletes szabályait a 78/2015. (XII. 23.) BM rendelet tartalmazza.

350/2016. (XI. 18.) Korm. rendelet a Nemzeti Szakértői és Kutató Központról 5. §.

Gergely Gárdonyi: Still Image Face Recognition in Hungary. Belügyi Szemle, 68. (2020), 3. 30.

78/2015. (XII. 23.) BM rendelet az arcképelemzô rendszer múködtetésének részletes szabályairól 5. § (1) és (5) bekezdések adnak rá felhatalmazást.
} 
nyilvántartást használ a rendszer. Ilyen a személyiadat- és lakcímnyilvántartás, a központi útiokmány-nyilvántartás, a közúti közlekedési nyilvántartás, a központi idegenrendészeti nyilvántartás, valamint a menekültügyi nyilvántartás. ${ }^{18}$ Ugyanakkor például a rabosítási felvételek vagy a diákigazolványok képei nem szerepelnek az adatbázisban, tehát ezek nem fognak eredményre vezetni a képek összevetésénél, holott nagy számban növelnék a találatok mennyiségét, ezáltal az azonosítás eredményességét. Amennyiben az azonosítás eredményre nem vezet, érdemes később ismételten beküldeni a képeket, hiszen azon túl, hogy a folyamatosan fejlődő technika mellett a szoftveres lehetőségek bővülnek, egyes okmányaink változhatnak, például új személyi igazolvány kiállításával új fotó kerül be a nyilvántartásba. Az idő előrehaladtával, vagy az új adatok bekerülésével tehát egy korábbi, sikertelen keresés is eredményre vezethet.

\subsubsection{Az arcképelemzés kritériumai}

Ahhoz, hogy pozitív eredményt kapjon az azonosításra beküldött kép, számos alapvető követelményeknek kell megfelelnie. Egyrészt fontos, hogy az azonosításra beküldött képen csak egy személy szerepelhet, ha ez nem megoldható, a kérelem benyújtása során egyértelműen meg kell jelölni, melyik az azonosítandó személy. Másrészt elengedhetetlen az azonosításra beküldött felvételek jó minősége. Ennek értelmében az azonosítandó személy két szeme között mért pupillatávolság minimum 50 pixel lehet, továbbá az arckép felbontása nem lehet kisebb, mint 0,3 megapixel, amelyen a személy arcának térfoglalása a felvétel kétharmada. Fontos továbbá, hogy a beküldött képek kizárólag „jpg” formátumúak lehetnek. Ezenkívül az azonosítandó felvételeken található személynek szemből kell a képen elhelyezkednie, tehát a fej dőlésszögének is jelentős szerepe van. Egyrészt az oldalirányú elfordulás nem haladhatja meg a 30 fokot, a függóleges billenés pedig tíz foknál nem lehet több. Komoly jelentősége van a megvilágítási tényezőknek, illetve a fény- és árnyékhatásoknak is. A túl sötét, életlen képek, vagy éppen a nagy villanófénnyel készített és az arc részleteit túlzottan megvilágító képek nem lesznek alkalmas az azonosításra, ezért az arc megvilágítása jól, szórt fénnyel kell történjen. Természetesen hátráltatja az azonosítást, ha az arcot eltakarják valamilyen kiegészítővel, például maszkkal, sállal, kapucnival, vagy esetleg napszemüveget visel az illető személy, de hátráltatja az azonosítást a becsukott szem is. ${ }^{19}$ Amennyiben több képpel rendelkezünk az azonosítani kívánt személyről, a hibalehetőségek minimalizálása érdekében célszerú

2015. évi CLXXXVIII. törvény az arcképelemzési nyilvántartásról és az arcképelemző rendszerről 4. § (1) bek.

11/2016. (IV. 29.) ORFK utasítás az arcképelemzési nyilvántartás és az arcképelemző rendszer igénybevételével kapcsolatos feladatokról 18. pont. 
olyat választani és azonosításra küldeni, amelyiknél nem áll fent a leírt azonosítást hátráltató vagy teljesen kizáró tényezők egyike. ${ }^{20}$

Ahogy Gárdonyi Gergely az arcképazonosítással kapcsolatban is kiemeli, az Egyesült Államok több államában, valamint egyes városaiban moratóriumot kértek az amerikai kormánytól az arcfelismerésre alkalmas kamerák nyílt vagy zárt térben történő elhelyezésére, vagy egyenesen tiltják is az alkalmazásukat. ${ }^{21}$

\subsection{A viselkedésalapú mesterséges intelligencia}

Az állóképes arcfelismerés mellett - amely, ahogy láthatjuk, a büncselekmények felderítését, a sértettek vagy elkövetők személyének beazonosítását szolgálja -, a viselkedésalapú mesterséges intelligencia megoldást jelenthetne a rendvédelmi szerveknek, hogy egyes bűncselekménytípusoknál, így a lopásnál, rablásnál, nemi erőszaknál, gépjárműfeltörésnél, betörésnél az elkövetők viselkedését zárt térben vagy közterületen észlelje és a megfelelő hatóságot értesítse. Mindamellett akár a kihallgatások, szembesítések vagy egyéb nyomozati cselekmények során az apróbb gesztusokat, testbeszédet felismerje, ezzel segítse a rendvédelem munkáját. Ennek egyik kétségtelen előnye lenne, hogy kisebb eséllyel lehetne a hatóságok éberségét kijátszani, ugyanakkor a fölösleges riasztások sem lennének kizárva, hiszen az emberi szándékot kizárólag a betanított mozdulatokból ismerné fel, a mögötte lévő érzelmi, gondolati tettet, cselekedetet nem lesz képes felismerni (például ki ne akart volna már valakit azzal meglepni, hogy hátulról befogja a szemét vagy ijeszti meg viccből a jó ismerősét az utcasarkon?!). Ugyanakkor a riasztás során küldött felvételekből, mivel ezek általában csak pillanatok, a felesleges elfogások száma is csökkenthető.

A viselkedésalapú biometrikus adatok a következők:

- kézírás: íráskép, dinamika;

- beszédhang;

- gépelési ritmus;

- mozgás: járásmód, a test helyzetének változásai. ${ }^{22}$

Persze jogosan merül fel a kérdés, hogy egy viszonylag néptelen környezetben, ahol az emberek mozgása szépen kivehető, mennyivel jelentene nehezebb feladatot egy jóval zsúfoltabb terület?

Myo Thida és kutatótársai két különböző modellezési technikát javasoltak az emberi tevékenység kimutatására és a tömegekben az egyes személyek nyomon követesére. A zsúfolt helyszíneken lévő, mozgó személyek sajátos mozgásmintáinak

20 Az Egyesült Államokban a kínai és orosz arcfelismerő rendszerek alkalmazását a kritikus infrastrukturális rendszerekben és a nemzetbiztonságban 2019 óta tiltja a törvény. John Honovich: Ban of Dahua and Hikvision Is Now US Gov Law. IPVM, 2018. augusztus 13.

21 Gárdonyi (2020): i. m.

22 Földesi Krisztina: A biometrikus azonosítási eljárások alkalmazhatósága a rendốri munkában. Doktori értekezés. Budapest, Óbudai Egyetem, 2017. 70. 
megismerése érdekében az úgynevezett makroszkopikus modellezési technikát alkalmazták. Ez az úgynevezett első típusú technika. A második típusú technika a mikroszkopikus modellezés, amely elsősorban a mozgó entitások úgynevezett videóútjának elemzésétől függ. Ez a modellezési technika azonban megragadja a tömegjelenetek normális mozgását, de nem érzékeli az egyes személyek cselekedeteinek részleteit. ${ }^{23}$

A két módszer együttes alkalmazása viszont a kirívó viselkedés, mondjuk egy futballmeccs vagy tüntetés során, hatalmas segítséget jelentene a tömegverekedések megelőzésére, akár a meccsek közben, akár pedig azokat követően.

De nemcsak a tömegrendezvények vagy fizikai jelenlét által okozott veszélyekre lenne képes felhívni a figyelmet, hanem a felhasználók viselkedésére az online térben, vagy akár a kockázatos weboldalak kiszűrésére is.

\subsection{A mesterséges intelligencia hazai jogszabályi háttere}

A mesterséges intelligenciával összefüggésben a jogi szabályozás még kidolgozás alatt van. Ugyanakkor kétségtelen, hogy annak mielőbbi keretek közé szorítása sürgető probléma, hiszen nemcsak előnyre lehet szert tenni általa, hanem visszaélésekre is alkalmas lehet. A jogi szabályozás mellett természetesen etikai kérdésekkel is foglalkoznak mind az Európai Unió szervezetei, mind pedig a tagállamok jogalkotói, kutatói.

Az MI-felhasználás jogi szabályozottsága mellett, az azt érintő, adatvédelmi kérdésekkel kapcsolatban ki kell emelni a 2016-ban az Európai Unióban életbe lépett Általános Adatvédelmi Rendeletet (General Data Protection, vagy röviden GDPR). A GDPR fogalma szerint biometrikus adatnak minősül egy természetes személy testi, fiziológiai vagy viselkedési jellemzőeire vonatkozó minden olyan sajátos technikai eljárásokkal nyert személyes adat, amely lehetővé teszi vagy megerősíti a természetes személy egyedi azonosítását, így például az arckép- vagy daktiloszkópiai adatot. Az arcot ábrázoló fényképek kezelését nem szükséges azonban szisztematikusan különleges adatkezelésnek tekinteni, mivel azokra csak azokban az esetekben vonatkozik a biometrikus adatok fogalommeghatározása, amikor a természetes személy egyedi azonosítását vagy hitelesítését lehetővé tévő speciális eszközzel kezelik őket. Ez alapján egy egyszerű, természetes személyt ábrázoló fénykép még nem minősül biometrikus adatkezelésnek, azonban ha a fényképeket egy arcfelismerő algoritmus kezeli, úgy az már biometrikus adatkezelésnek számít. ${ }^{24}$ Ugyanakkor, ahogy azt az adatvédelmi rendeletben is kiemelik: a személyes adat különleges kategória, és az ebbe a körbe tartozó biometrikus adatoknak a kezelése tilos, tekintettel arra, hogy az alapvető jogok és szabadságok szempontjából a természetüknél fogva

\footnotetext{
23 Myo Thida et al.: A Literature Review on Video Analytics of Crowded Scenes. In Pradeep K. Atrey - Mohan S. Kankanhalli - Andrea Cavallaro (szerk.): Intelligent Multimedia Surveillance. Springer, 2013. 17-36.

24 Kovács Tibor - Miklós Gellért: A biometrikus adatok kezelésének jogi szabályozása. Hadmérnök, 14. (2019), 1. 8-16.
} 
különösen érzékeny személyes adatok egyedi védelmet igényelnek, mivel az érintettek jogaira nézve a kezelésük körülményei jelentős kockázatot hordozhatnak. ${ }^{25}$

$\mathrm{Az}$ arcképelemzési adatbázisról és az arcképelemző rendszerről szóló 2015. évi CLXXXVIII. törvény új elemként jelent meg mind a magyar jogrendszerben, mind a közvéleményben. Ennek egyik alapja az arcképprofil-nyilvántartás. Alkalmazásának számos célja van, egyrészt bủncselekmények megelőzése, megakadályozása, felderítése és megszakítása, az elkövetők elfogása és felelősségre vonása, másrészt a büntetés-végrehajtási intézetbe való befogadás során az elítélt és a fogvatartott személyek azonosítása, esetleg egyes személyek azonosítása, eltűnt személyek felkutatása. További cél lehet a nemzetbiztonsági szolgálatok egyes feladatai és a titkos információgyüjtés folytatására, leplezett eszközök alkalmazására feljogosított szervek tevékenységének támogatása, továbbá nemzetbiztonsági ellenőrzés, felderítési, nemzetbiztonsági védelmi és elhárítási, információszerzési, nemzetbiztonsági, iparbiztonsági, belső biztonsági és bủnmegelőzési ellenőrzési feladataik támogatása, az objektumok műveleti védelme, esetleg rendőri intézkedéssel érintett személyek személyazonosságának megállapítása, ellenőrzése. Mindezeken kívül a törvény számos egyéb más célt részletez. ${ }^{26}$

Feltételezhetjük, hogy egy olyan komplex rendszer, mint az állóképes arcképazonosító rendszer túl sok érzékeny adatot tárolhat, gyüjthet az érintett személyekről, amelyek adatvédelmi aggályokat eredményezhetnek. Tudni kell azonban, hogy az NSZKK mindössze három metaadatot ${ }^{27}$ kezel a nyilvántartásokban levő személyek arcképeivel összefüggésben: ez a születési év, az illető neve, illetve a kép készítésének időpontja. E három adatra végezhető el csak a szűrés is. A jogszerűséget hivatott szolgálni az a tény, hogy a lehető legkevesebb személyes adatot tárolja a rendszer. Ugyanakkor biztosítani kell azok átláthatóságát, valamint az emberi beavatkozás lehetőségét. Utóbbinak megfelel a két, egymás tevékenységétől független elemző jelenléte, akik folytán nem beszélhetünk kizárólag algoritmikus alapon meghozott döntésekről, hiszen az elemzett képek felülvizsgálatra kerülnek. Fontos tudni, hogy az elemző nincs tisztában azzal, hogy kinek a képét és milyen célból kell elemeznie, továbbá jelenteniük kell minden olyan gyanús tényezőt, amely az elemzés befolyásolhatóságát eredményezheti. Az arcképelemző tevékenységet egy speciális, erre kialakított elemzőhelyiségben végzik, amely a végző szerv egyéb, jogszabály által előírt feladatainak ellátására szolgáló más objektumtól fizikailag el van különítve, továbbá saját beléptetőrendszerrel van felszerelve. ${ }^{28}$ További biztosíték, hogy az adott képet automatikusan törli a rendszer az elemzés befejezése után.

\footnotetext{
25 Az Európai Parlament és a Tanács (EU) 2016/679. számú Rendelete, a természetes személyeknek a személyes adatok kezelése tekintetében történő védelméről és az ilyen adatok szabad áramlásáról, valamint a 95/46/EK rendelet hatályon kívül helyezéséről (általános adatvédelmi rendelet) Preambulum (2).

26 2015. évi CLXXXVIII. törvény 3. § (3) bek.

27 A metaadat legegyszerúbb definíciója: adat az adatról. Pontosabban, a metaadat írja le az adatot, azaz olyan információkkal szolgál, mint típus, hosszúság, szöveges leírás és más jellemzők. A metaadat válaszol az adat felhasználóinak a ki, mit, mikor, hol, miért és hogyan kérdésekre.

28 78/2015. (XII. 23.) BM rendelet 1. §.
} 


\subsection{Jövôbeli hasznosítás}

Magyarországon az állóképes arcképazonosító rendszer folyamatos fejlesztés alatt áll. Egyrészt szoftveres szempontból a rendszer üzemeltetője által, másrészt gyakori jelleggel fejlesztési javaslatokat tesznek a Belügyminisztérium illetékes osztályának, támogatva a rendszer múködését. Az előzetes képfeldolgozási eljárások további kiterjesztése - amelyek jelenleg kísérleti szakaszban vannak - szintén jó lehetőségeket kínálnak, de ezenkívül a szakértôk számos más, az elemzés könnyítését és hatékonyságát szolgáló módszerek kifejlesztésén dolgoznak. ${ }^{29}$

Az MI által biztosított arcfelismerési technológia segít a csalásokban és személyazonosság-lopásokban érintett gyanúsítottak letartóztatásában is. Az egynél több személyazonossággal rendelkező személyek azonosításához elemezni kell a vezetői engedélyhez csatolt képet, és össze kell hasonlítani azokat az egyéb képekkel, amelyek már szerepelnek az adatbázisban. Ez olyan csalók és személyi tolvajok azonosításához vezetett, akik ellopott személyazonossággal vagy egynél több engedéllyel manipulálják az adminisztrációt. Ez szintén hasznos abban, hogy a rakoncátlan sofőröket távol tartsák az úttól, növelve a többi sofőr és jármü biztonságát. Amikor a vezetői engedélyt visszavonják, a sofőrnek nem szabad vezetnie. Olyan technológiával, mint a kamerák, a videók és a közösségi média, hatalmas mennyiségủ adat alapján a mesterséges intelligencia észlelheti azokat a bủncselekményeket, amelyek egyébként észrevétlenek maradnának, és hozzájárulhat a nagyobb közbiztonság biztosításához az esetleges bủncselekmények kivizsgálásával, ezáltal növelve a közösség bizalmát a bűnüldözés és a büntető igazságszolgáltatás iránt.

A folyamatosan megjelenő innovatív technológiák és módszerek alkalmazása a rendészeti szerveknél is elengedhetetlen, de ugyanilyen fontos az arcképelemző rendszerek - jelen esetben az állóképes arcképazonosító rendszer - múködésének ismertetése, bemutatása, képzések biztosítása az állomány részére. A hazai képzéseken túl az Interpol és egyes munkacsoportok által folytatott, ezirányú oktatást biztosító képzések, nemzetközi kapcsolatok is meglehetősen előnyösek lehetnek, napjainkban pedig kifejezetten hasznosak, ahol a hagyományos büncselekmények mellett egyre nagyobb számban fordulnak elő a számítástechnikával összefüggő, a kibertérben előforduló búncselekmények is.

Az MI videó- és képalgoritmusok nemcsak bonyolult feladatokat képesek megtanulni, hanem ki tudják fejleszteni és meg tudják határozni azoknak a saját, független, komplex arcfelismerési jellemzőit és paramétereit. Ezeknek a feladatoknak a teljesítéséhez, azon túl, amit az ember figyelembe vehet, az algoritmusok képesek megfeleltetni az arcokat, azonosítani a fegyvereket és más tárgyakat, és felismerni olyan összetett eseményeket, mint például a balesetek és bűncselekmények, legyenek azok akár folyamatban lévők vagy befejezettek.

29 Gárdonyi (2020): i. m. 31. 
Álláspontunk szerint a technológia fejlődése nem megkerülhető folyamat, azzal együtt kell élni, vele együtt kell fejlődni. Ahogyan a kérdőives kutatásból is leszűrhető, a rendvédelemben dolgozók nagyobb része nem ismeri a mesterséges intelligenciát, ugyanakkor el tudná képzelni annak felhasználását a munkája során.

A tanulmányban röviden felvillantottuk azokat a területeket, amelyeken az MI segítené, de nem helyettesítené a rendvédelmi szervek munkáját, mint a közterületi feladatokat ellátó rendőr munkájának segítése akár éjszaka vagy pedig nagyobb tömegrendezvények során. A bűnügyi feladatokban a digitális nyomrögzítésben, bizonyítékok rendszerezésében és értékelésében jelenthet segítséget, mindamellett, hogy költséghatékonyabb is, mint a szakértők díjának megfizetése.

\section{IRODALOMJEGYZÉK}

Dobó Judit: A mesterséges intelligencia alkalmazása a rendvédelemben. NKE RTK Tudományos Diákköri Konferencia, 2020. november 4.

Földesi Krisztina: A biometrikus azonositási eljárások alkalmazhatósága a rendöri munkában. Doktori értekezés. Budapest, Óbudai Egyetem, 2017. Online: https://bdi.uni-obuda.hu/sites/default/ files/Doktori_(PhD)_ertekezes-Foldesi_Krisztina.pdf

Gárdonyi, Gergely: Still Image Face Recognition in Hungary. Belügyi Szemle, 68. (2020), 3. 2233. Online: https://doi.org/10.38146/BSZ.SPEC.2020.3.2

Honovich, John: Ban of Dahua and Hikvision Is Now US Gov Law. IPVM, 2018. augusztus 13. Online: https://ipvm.com/reports/ban-law

Kollár Csaba: A mesterséges intelligencia kapcsolata a humán biztonsággal. Nemzetiztonsági Szemle, 6. (2018), 1. 5-23. Online: https://doi.org/10.32561/nsz.2018.1.1

Kollár Csaba: A mesterséges intelligencia és a kapcsolódó technológiák bemutatása a biztonságtudomány fókuszában. In Rajnai Zoltán (szerk.): Kiberbiztonság/Cybersecurity 2. Budapest, Biztonságtudományi Doktori Iskola, 2019. 47-61.

Kovács Tibor - Miklós Gellért: A biometrikus adatok kezelésének jogi szabályozása. Hadmérnök, 14. (2019), 1. 8-16. Online: https://doi.org/10.32567/hm.2019.1.1

McCulloch, Warren - Walter Pitts: A Logical Calculus of the Ideas Immanent in Nervous Activity. Bulletin of Mathematical Biophysics, 5. (1943). 115-133. Online: https://doi.org/10.1007/ BF02478259

Németh Attila - Tóth Gergely: Arcfelismerő rendszerek alkalmazása. Belügyi Szemle, 67. (2019), 1. 127-136. Online: https://doi.org/10.38146/BSZ.2019.1.10

Szalavetz Andrea: Mesterséges intelligencia és technológiavezérelt termelékenységemelkedés. Külgazdaság, 63. (2019), 7-8. 53-79. Online: https://doi.org/10.47630/KULG.2019.63.7-8.53

Thida, Myo - Yoke L. Yong - Pau Climent-Perez - How-lung Eng - Paolo Remagnino: A Literature Review on Video Analytics of Crowded Scenes. In Pradeep K. Atrey - Mohan S. Kankanhalli - Andrea Cavallaro (szerk.): Intelligent Multimedia Surveillance. Springer, 2013. 1736. Online: https://doi.org/10.1007/978-3-642-41512-8_2

Warren McCulloch, Walter Pitts: A Logical Calculus of the Ideas Immanent in Nervous Activity (Bulletin of Mathematical Biophysics, vol.5, 1943). Online: https://doi.org/10.1007/ BF02478259 


\section{Jogforrások}

2015. évi CLXXXVIII. törvény az arcképelemzési nyilvántartásról és az arcképelemző rendszerről 350/2016. (XI. 18.) Korm. rendelet a Nemzeti Szakértői és Kutató Központról

78/2015. (XII. 23.) BM rendelet az arcképelemző rendszer működtetésének részletes szabályairól 11/2016. (IV. 29.) ORFK utasítás az arcképelemzési nyilvántartás és az arcképelemző rendszer igénybevételével kapcsolatos feladatokról

Az Európai Parlament és a Tanács (EU) 2016/679. számú Rendelete, a természetes személyeknek a személyes adatok kezelése tekintetében történő védelméről és az ilyen adatok szabad áramlásáról, valamint a 95/46/EK rendelet hatályon kívül helyezéséről (általános adatvédelmi rendelet)

\section{ABSTRACT}

\section{Some Uses of Artificial Intelligence in Law Enforcement \\ Judit DOBÓ - Réka GYARAKI}

We have all heard of artificial intelligence, but few realise how much it interweaves and determines the technological development of our time. However, in addition to popular economic and scientific interests, it is just as important for it to do useful service in the field of public safety. At the same time the future use of Al will pose serious challenges to both law enforcement and legislation. How can these challenges be dealt with will be a key issue for the times to come.

Keywords: artificial intelligence, law enforcement, analysis, face recognition 